\title{
Pengaruh Model Pembelajaran M-APOS Berbantuan Portal Rumah Belajar terhadap Kemampuan Pemahaman Konsep Matematis Siswa di SMKN 26 Jakarta
}

\author{
Rizka Auliya $^{1, \text { a), }}$ Pinta Deniyanti Sampoerno ${ }^{2, b)}$, Aris Hadiyan Wijaksana ${ }^{3, \text { c) }}$ \\ ${ }^{123}$ Universitas Negeri Jakarta, Rawamangun, Jakarta Timur \\ Email: a)rizkaauliyaaa@gmail.com
}

\begin{abstract}
Abstrak
Penelitian ini bertujuan untuk mengetahui a pakah penerapan modelpembelajaran M-APOS berbantuan Portal Rumah Belajar dapat mempengaruhi kemampuan pemahaman konsep matematis siswa di SMKN 26 Jakarta. Penelitian ini merupakan penelitian kuantitatif, dengan metode quasi experiment. Desain yang digunakan adalah Posttest-only Control Design. Popula sinya adalah seluruh siswa kelas X di SMKN 26 Jakarta. Teknik pengambilan sampel menggunakan teknik purposive sampling dan cluster random sampling. Kelas X TMPO 2 sebagai kelas eksperimen dan kelas X TMPO 1 sebagai kelas kontrol. berdasarkan hasil pengujian menggunakan uji t' diperoleh rata -rata kemampuan pemahaman konsep matematis siswa kelas eksperimen lebih tinggi daripada kelas kontrol. Hal ini menunjukkan bahwa terdapat pengaruh model pembelajaran M-APOS berbantuan Portal Rumah Belajar terhadap kemampuan pemahaman konsep matematis siswa di SMKN 26 Jakarta.
\end{abstract}

Kata kunci: model pembelajaran M-APOS, portal rumah belajar, kemampuan pemahaman konsep matematis.

\section{PENDAHULUAN}

Matematika merupakan ilmu yang berperan penting di dunia pendidikan dalam perkembangan daya pikir manusia dan juga perkembangan ilmu pengetahuan dan teknologi (IPTEK). Perkembangan dan kemajuan teknologi sangat erat kaitannya dengan ilmu matematika. Pada saat ini, apabila seseorang tidak mengenal teknologi maka seseorang tersebut sulit bersaing di dunia luar. Untuk menguasai teknologi di masa depan perlunya penguasaan matematika sejak dini. Salah satu kegiatan yang menunjang keberhasilannya dalam penguasaan matematika yaitu dengan proses belajar matematika yang diterapkan di sekolah.

Matematika bukanlah pelajaran hafalan, untuk menyelesaikan permasalahan matematik, siswa bukan hanya menghafal rumus melainkan siswa harus memahami konsep rumu s itu terbentuk dan kegunaannya dalam kehidupan sehari hari. Belajar konsep merupakan hal yang paling mendasar dalam proses belajar matematika, oleh karena itu seorang pendidik dalam mengajarkan konsep harus beracuan pada sebuah tujuan yang dicapai (Erma Monariska, 2017). Maka perlunya pe mahaman konsep dasar pada siswa sehingga semakin tinggi pemahaman konsep siswa tentang materi, maka semakin tinggi pula tingkat keberhasilan tujuan pembelajaran matematika di sekolah.

Pemahaman konsep matematis adalah mengerti benar tentang konsep matematika, yaitu sisw a dapat menerjemahkan, menaf sirkan, dan menyimpulkan suatu konsep matematika berdasarkan pembentukan pengetahuanya sendiri, bukan menghafal (Vivi Utari, 2012). Pemahaman konsep matematis merupakan kemampuan yang berhubungan dengan penguasaan konsep-konsep yang melibatkan operasi, relasi, dan generalisasi dalam proses pembelajaran matematika (Sutrianin gsih, 2018). 
Namun, pada kenyataannya kemampuan pemahaman konsep matematis siswa di Indonesia masih tergolong rendah. Berdasarkan hasil data statistik dari Pusat Penilaian Pendidikan, Kemendikbud menunjukkan hasil Ujian Nasional pada 3 tahun terakhir, yaitu tahun 2016, 201 7, dan 2018 bahwa nilai matematika siswa Indonesia khususnya tingkat SMK masih sangat rendah. Hal ini juga dapat dilihat dari persentase siswa yang menjawab benar dari dua contoh soal Ujian Nasional yang mengukur indikator kemampuan pemahaman konsep matematis bahwa dari ju mlah 957.378 siswa yang mengikuti Ujian Nasional, persentase siswa yang menjawab benar pada kedua soal yaitu materi program linear dan trigonometri hanya $41,47 \%$ dan $31,36 \%$. Maka dapat disimpulkan bahwa persentasi siswa yang benar dalam menjawab soal tersebut kurang dari $50 \%$ atau tidak mencapai setengah dari peserta Ujian Nasional. Di SMKN 26 Jakarta itu sendiri kemampuan pemahaman konsep matematis siswa juga masih tergolong rendah, hal ini dapat dilihat dari hasil penilaian harian siswa pada materi program linear yang mengukur indikator kemampuan pemahaman konsep matematis dimana hanya 11 dari 36 siswa yang nilainya mencapai $\mathrm{kkm}$.

Salah satu faktor penyebab rendahnya kemampuan pemahaman konsep matematis ialah pembelajaran yang masih berpusat pada guru, sehingga siswa cenderung pasif dan kurang melatih kemampuan berpikirnya. Maka dari itu dibutuhkan pembelajaran yang melibatkan sisw a secara aktif dan dapat mengkonstruksikan pemahamannya sendiri. Maka salah satu penerapan pembelajaran yang cocok adalah model pembelajaran M-APOS berbantuan Portal Rumah Belajar. Model pembelajaran M-APOS merupakan modifikasi dari suatu Teori APOS yang dikembangkan oleh Ed Dubinsky. Modifikasi yang dimaksud adalah pada fase aksi, dimana kegiatan di laboratorium komputer, diganti menjadi pemberian tugas resitasi yang diberikan sebelum pembelajaran dilaksanakan. Pemberian tugas resitasi yang disajikan berupa Lembar Kerja Tugas (LKT) yang menuntun dan membantu siswa dalam mengkaji pemahaman konsep dalam menyelesaikan persoalan matematika. Pada tahap ini diharapkan siswa sudah memahami konsep yang akan dipelajari selanjutnya sehingga memudahkan siswa untuk mengikuti materi yang akan dipelajari dengan kemampuan matematis (Noviana, 2016). Terdapat tiga fase pembelajaran ini, yaitu Aktivitas, Diskusi Kelas, dan Latihan Soal.

Selanjutnya model pembelajaran M-APOS ini berbantuan Portal Rumah Belajar. Pustekkom Kemdikbud telah membuat dan mengembangkan Rumah Belajar sejak tahun 2011 sebagai salah satu portal pembelajaran berbasis web, yang berisi berbagai layanan pembelajaran seperti Kelas Maya, Lab Maya, Sumber Belajar, dan Peta Budaya dengan alamat http://belajar.kemdikbud.go.id (Pustekkom: Pedoman Pemanfaatan Portal Rumah Belajar). Pada Portal Rumah Belajar tersedia layanan: (1) berbagai sumber belajar, (2) pelatihan atau kursus bagi guru dan masyarakat, (3) soalsoal latihan untuk meningkatkan tingkat kompetensi peserta didik, dan (4) bimbingan belajar bagi peserta didik (Supandri, 2018).

\section{METODE}

Penelitian ini menggunakan jenis penelitian kuantitatif dengan metode penelitian quasi experiment yang memiliki dua kelompok penelitian, yaitu kelas eksperimen yang memperoleh perlakuan berupa pembelajaran menggunakan model M-APOS berbantuan Portal Rumah Belajar dan kelas kontrol yang memperoleh perlakuan berupa pembelajaran konvensional. Desain yang digunakan pada penelitian ini berbentuk Posttest-only Control Design yang digunakan untuk mengetahui pengaruh pembelajaran model M-APOS berbantuan Portal Rumah Belajar terhadap kemampuan pemahaman konsep matematis siswa di SMKN 26 Jakarta. Desain yang dugunakan dapat dilihat pada Tabel 1 .

TABEL 1. Desain Penelitian

\begin{tabular}{|c|c|c|}
\hline Kelas & Perlakuan & Tes \\
\hline $\mathrm{K}_{\mathrm{E}}$ & $\mathrm{P}$ & $\mathrm{Y}$ \\
\hline $\mathrm{K}_{\mathrm{K}}$ & - & $\mathrm{Y}$ \\
\hline
\end{tabular}

Keterangan:

$\mathrm{K}_{\mathrm{E}}:$ Kelas Eksperimen 
$\mathrm{K}_{\mathrm{K}}:$ Kelas kontrol

P : Perlakuan berupa model pembelajaran M-APOS berbantuan Portal Rumah Belajar

- : Perlakuan berupa pembelajaran konvensional berbantuan Portal Rumah Belajar

$\mathrm{Y}$ : Tes kemampuan pemahaman konsep matematis siswa

Variabel pada penelitian ini adalah menggunakan dua variabel yaitu variabel bebas dan variabel terikat, dimana variabel bebasnya adalah model pembelajaran M-APOS berbantuan Portal Ru mah Belajar. Sedangkan variabel terikat pada penelitian ini adalah kemampuan pemahaman konsep matematis.

Penelitian ini dilakukan di SMKN 26 Jakarta, dengan populasinya seluruh siswa kelas X di SMKN 26 Jakarta tahun ajaran 2018/2019 yang terdiri dari 14 kelas. Pengambilan sampel pada penelitian ini dilakukan dengan menggunakan teknik Two Stages Sampling, yaitu penentuan sampel dengan dua langkah.

Teknik pertama pemilihan sampel, yaitu memilih kelas yang diajarkan oleh guru yang sama dengan teknik purposive sampling, terpilih tujuh kela yang diajar oleh guru yang sama. Teknik kedua dengan cluster random sampling, yaitu pengambilan anggota populasi dilakukan secara acak tanp a memerhatikan strata yang ada dalam populasi tersebut. Didapat kelas X TMPO 2 sebagai kelas eksperimen dengan total 35 siswa dan kelas X TMPO 1 sebagai kelas kontrol dengan total 36 siswa.

Data yang digunakan pada penelitian ini adalah Penilaian Akhir Semester Ganjil tahun ajaran 2018/2019 dan nilai hasil tes kemampuan pemahaman konsep matematis setelah diberikan perlakuan pada kelas eksperimen dan kelas kontrol. Nilai Penilaian Akhir Semester Ganjil tahun ajaran 2018/2019 digunakan sebagai data untuk uji analisis data sebelum perlakuan kelas ek sperimen dan kekas kontrol. Kemudian Tes kemampuan pemhaman konsep matematis y ang digu nak an berupa empat soal uraian untuk mengukur kemampuan pemahaman konsep matematis siswa setelah diberikan perlakuan. Kemampuan pemahaman konsep matematis yang dapat diukur dari soal -s oal yang diberikan meliputi: (1) menyatakan ulang konsep yang telah dipelajari, (2) mengklasifikasikan objek-objek berdasarkan konsep matematika, (3) menerapkan konsep secara algoritma, (4) menyajikan konsep dalam berbagai representasi, dan (5) mengaitkan berbagai konsep matematika secara internal atau eksternal.

Sebelum instrumen digunakan dalam penelitian ini, maka perlu dilakukan validasi isi dan konstruk yang dilakukan oleh ahli yaitu Dosen Pendidikan Matematika Universitas Negeri Jakarta dan Guru Mata Pelajaran Matematika. Kemudian soal yang sudah divalidasi oleh ahli diujic obak an pada siswa untuk mengetahui validitas empiris dan reliabilitas. Hasil validasi isi, konstruk, dan empiris tes kemampuan pemahaman konsep matematis dinyatakan bahwa instrumen tersebut valid, demikian halnya dengan uji reliabilitas. Maka dari itu instrumen tes kemampuan pemahaman konsep matematis layak digunakan dalam penelitian ini.

Teknik analisis data yang digunakan dalam penelitian ini adalah dengan uji prasyarat menggunakan uji normalitas dan uji homogenitas. Uji normalitas sebelum dan sesudah perlakuan dalam penelitian ini menggunakan uji Liliefors, sedangkan untuk uji homogenitas sebelum perlakuan menggunakan uji Bartlett dan setelah perlakuan menggunakan uji Fisher (Sudjana, 2005).

Selain itu pengujian hipotesis pada penelitian ini dilakukan dengan teknik uji statistik yang cocok dengan distribusi yang diperoleh. Setelah normalitas dan homogenitas data diketahui, maka dalam pengujian hipotesis penelitian akan diuji dengan menggunakan uji t' dikarenakan data tersebut tidak homogen. Adapun hipotesis yang digunakan dalam penelitian ini adalah:

$H_{O}$ : Kemampuan pemahaman konsep matematis siswa yang belajar menggunakan model pembelajaran M-APOS berbantuan Portal Rumah Belajar lebih rendah sama dengan kemampuan pemahaman konsep matematis siswa yang belajar dengan pembelajaran konvesional).

$H_{1}$ : Kemampuan pemahaman konsep matematis siswa yang belajar menggunakan model pembelajaran M-APOS berbantuan Portal Rumah Belajar lebih tinggi dari kemampuan pemahaman konsep matematis siswa yang belajar dengan pembelajaran konvesional).

Rumus Uji t' yang digunakan, yaitu: 
(Sudjana, 2005)

$$
t^{\prime}=\frac{\bar{x}_{1}-\bar{x}_{2}}{\sqrt{\frac{s_{1}^{2}}{n_{1}}+\frac{s_{2}^{2}}{n_{2}}}}
$$

Keterangan:

$\bar{x}_{1}=$ rata-rata nilai kelas eksperimen

$\bar{x}_{2}=$ rata-rata nilai kelas kontrol

$s_{1}{ }^{2}=$ varians kelas eksperimen

$s_{2}{ }^{2}=$ varians kelas kontrol

$n_{1}=$ banyaknya anggota kelas eksperimen

$n_{2}=$ banyaknya anggota kelas kontrol

Dengan kriteria pengujian:

Terima $\mathrm{H}_{0} \mathrm{jika} t_{\text {hitung }}<\frac{w_{1} t_{1}+w_{2} t_{2}}{w_{1}+w_{2}}$, dengan:

$w_{1}=\frac{s_{1}^{2}}{n_{1}} ; w_{2}=\frac{s_{2}^{2}}{n_{2}}$

$t_{1}=t_{(1-\alpha),\left(n_{1}-1\right)}$

$t_{2}=t_{(1-\alpha),\left(n_{2}-1\right)}$.

\section{HASIL DAN PEMBAHASAN}

Data hasil uji tes kemampuan pemahaman konsep matematis siswa pada kelas eksperimen dan kelas kontrol dapat dilihat pada Tabel 2.

TABEL 2. Hasil Statistika Deskriptif

\begin{tabular}{|c|c|c|}
\hline Statistik Deskriptif & Kelas Eksperimen & Kelas Kontrol \\
\hline Nilai Minimum & 45.83 & 25 \\
\hline Nilai Maksimum & 87.5 & 79.167 \\
\hline Jangkauan data & 41.67 & 54.167 \\
\hline Rata-rata (mean) & 67.62 & 51.85 \\
\hline Modus & 58.33 & 54.167 \\
\hline Quartil 1 & 58.33 & 41.67 \\
\hline Quartil 2 & 66.67 & 54.167 \\
\hline Quartil 3 & 75 & 62.5 \\
\hline Jangkauan antar-quartil & 16.67 & 20.83 \\
\hline Simpangan baku & 11.39 & 15.32 \\
\hline Ragam/Varians & 129.79 & 234.57 \\
\hline
\end{tabular}

Berdasarkan Tabel 2 dapat dilihat bahwa nilai ukuran pemusatan data kelas eksperimen lebih tinggi dibandingkan kelas kontrol. sedangkan ukuran penyebaran data kelas eksperimen lebih rend ah dibandingkan kelas kontrol, yang artinya data pada kelas kontrol kebih menyebar. Apabila uji normalitas dan homogenitas telah diketahui selanjutnya diuji dengan uji hipotesis dengan menggunakan uji t' dikarenakan data tersebut tidak homogen. Jika jika $t_{\text {hitung }}<\frac{w_{1} t_{1}+w_{2} t_{2}}{w_{1}+w_{2}}$, maka keputusan adalah terima $H_{0}$, yaitu kemampuan pemahaman konsep matematis siswa kelas eksperimen lebih rendah dibandingkan kemampuan pemahaman konsep matematis siswa kelas kontrol.

Hasil perhitungan diperoleh $t_{\text {hitung }}=4,931121$ dan $\frac{w_{1} t_{1}+w_{2} t_{2}}{w_{1}+w_{2}}=0,031565$ dengan $t_{\text {hitung }}>\frac{w_{1} t_{1}+w_{2} t_{2}}{w_{1}+w_{2}}$, sehingga $H_{0}$ ditolak dan dapat disimpulkan bahwa setelah diberikan perlakuan yang berbeda, terdapat perbedaan rata-rata skor tes kemampuan pemahaman konsep matematis siswa kelas eksperimen dan kelas kontrol, dengan rata-rata kemampuan pemahaman konsep matematis 
siswa yang belajar menggunakan model pembelajaran M-APOS berbantuan Portal Rumah Belajar lebih tinggi dari kemampuan pemahaman konsep matematis siswa yang belajar dengan pembelajaran konvesional. Hal ini menunjukkan bahwa terdapat pengaruh penerapan model pembelajaran $\mathrm{M}$ APOS berbantuan Portal Rumah Belajar terhadap kemampuan pemahaman konsep matematis sis wa di SMKN 26 Jakarta dengan taraf signifikansi $\alpha=0,05$.

\section{PENUTUP}

Berdasarkan hasil dan pembahasan diperoleh kesimpulan bahwa kemampuan pemahaman konsep matematis siswa SMKN 26 Jakarta pada materi Matriks yang belajar menggunakan model pembelajaran M-APOS berbantuan Portal Rumah Belajar lebih tinggi daripada sis wa y ang belajar menggunakan pembelajaran konvensional. Dengan demikian dapat disimpulkan bahwa terdapat pengaruh kemampuan pemahaman konsep matematis siswa SMKN 26 Jakarta pada materi Matriks.

\section{REFERENSI}

Monariska, Erma. 2017. "Penerapan Metode Mind Mapping untuk Meningkatkan Kemampuan Pemahaman Konsep Matematis Mahasiswa pada Mata Kuliah Kalkulus I." Jurnal PRISMA Universitas Suryakancana Volume 6, Nomor 1.

Noviana, Widyah, Suyono, dan Lukman El Hakim. 2018. "Pengaruh Pendekatan M-APOS Terhadap Kemampuan Penalaran Matematis Siswa SMP Negeri di Kota Tangerang." Jurnal Riset Pendidikan Matematika Jakarta Volume 1 Nomor 1.

Sudjana. 2005. Metoda Statistika Edisi 6. Bandung: Tarsito.

Supandri. 2018. "Faktor-Faktor Penyebab Guru Belum Optimal Memanfaatkan Portal Rumah Belajar dalam Kegiatan Pembelajaran”. Jurnal TEKNODIK, Volume 22 Nomor 1.

Sutrianingsih. 2017. "Pengaruh Model Pembelajaran Group Investigation Terhadap Pemahaman Konsep Dan Self Efficacy Ditinjau Dari Kemampuan Awal Matematika SMP Negeri Kecamatan Pulogadung Jakarta Timur.” Tesis. Jakarta: Pascasarjana Universitas Negeri Jakarta.

Utari, Vivi. 2012. "Peningkatan Kemampuan Pemahaman Konsep Melalui Pendekatan PMR Dalam Pokok Bahasan Prisma dan Limas.” Jurnal Pendidikan Matematika Volume 1, Nomor 1. 